\title{
Role of Bacterial and Parasitic Pathogens in Occurrence of Neonatal Diarrhoea in Goat-Kids
}

\author{
Anil K. Mishra ${ }^{1}$, Desh Deepak Singh ${ }^{2 *}$, Naveen Kumar ${ }^{3}$, Gururaj Kumarsen ${ }^{1}$, Souvik Paul ${ }^{4}$ and Ashok Kumar ${ }^{1}$ \\ ${ }^{1}$ Division of Animal Health, ICAR-Central Institute for Research on Goats, Makhdoom, Farah Mathura, Uttar Pradesh, INDIA \\ ${ }^{2}$ Department of Veterinary Pathology, College of Veterinary Sciences, ANDUAET, Ayodhya Uttar Pradesh, INDIA \\ ${ }^{3}$ Veterinary Type Culture Collection, National Research Centre on Equines, Bagla Road, Hisar Haryana, INDIA \\ ${ }^{4}$ ICAR-National Research Centre on Pigs, Guwahati Assam, INDIA \\ *Corresponding author: DD Singh; E-mail:drdd2005@gmail.com
}

Received: 09 April, 2020

Revised: 13 May, 2020

Accepted: 17 May, 2020

\begin{abstract}
Infectious diarrhoea in neonates of animals is one of the most common and economically important conditions encountered in the livestock industry. Faecal samples $(n=210)$ from diarrhoeic neonatal goat-kids of different livestock sheds of ICAR-CIRG, Makhdoom, Mathura (U.P.), were aseptically collected, and immediately processed for isolation of bacterial pathogens and parasitic evaluation. A total of 178 isolates of E. coli from 210 samples were identified on the basis of cultural, morphological, biochemical and molecular characteristics. Out of $178 \mathrm{E}$. coli isolates, $3.93 \%(7 / 178)$ isolates were identified as STEC by PCR amplification of stx-1 and stx-2 gene. A total of 64 isolates of E. coli were sent to National Salmonella and Escherichia Centre, Central Research Institute, Kasauli for the serotyping. The common serogroups of $E$. coli responsible for neonatal diarrhoea in goat-kids were identified as $\mathrm{O} 36, \mathrm{O} 26, \mathrm{O} 59, \mathrm{O} 29, \mathrm{O} 43, \mathrm{O} 91, \mathrm{O} 82, \mathrm{O} 9$ and $\mathrm{O} 171$, out of which, 46.15\% were O36, O26 and O59. Cryptosporidium spp. infection was detected in 46 samples out of 148 faecal samples by ZN staining and nested PCR.Based on cultural, morphological, biochemical and molecular characteristics, 16 isolates of Salmonella spp. and 5 of Klebsiella spp. were identified from 210 fecal samples. The present study concluded that E. coli followed by Cryptosporidium spp. and Salmonella spp. were the prevalent infectious agents associated with neonatal diarrhoea in goat-kids.
\end{abstract}

Keywords: E. coli, Salmonella, Cryptosporidium, Klebsiella, Goat-Kids, Neonatal-Diarrhoea

The major problem encountered in goat farming is higher morbidity/mortality among neonatal kids, which leads to severe economic loss to goat farmers/entrepreneurs. Many factors contribute to the mortality in neonatal goat-kids. Diarrhoea is the single major cause of mortality in neonatal goat-kids (Singh et al., 2018). Infectious diarrhoea in neonates of farm animals is one of the most common and economically devastating conditions encountered in the livestock industry (Draksler et al., 2002). The infectious causes of diarrhoea have been well studied in cattle, pigs and lambs; however, not much work has been done in India/abroad to determine the enteric pathogens that cause diarrhoea in goat-kids (Smith and Sherman, 2009). Diarrhoea during the first month after birth is important cause of mortality in neonates of the farm animals
(Radostits et al., 2006). The mortality due to diarrhoea may be as high as $60 \%$ (Kritas, 2002). In goat-kids, Escherichia coli, Salmonella spp. and Cryptosporidium spp. are considered as the most prevalent organisms associated with diarrhoea (Ozmen et al., 2006; Paul et al., 2014). Among the diarrhoegenic bacterial pathogens in neonatal animals, E. coli and Salmonella spp. are the most common and economically most important (Coura et al., 2015). Cryptosporidium spp. may cause mortality up to $40 \%$ leading to severe economic loss to farmers

How to cite this article: Mishra, A.K., Singh, D.D., Kumar, N., Kumarsen, G., Paul, S. and Kumar, A. (2020). Role of bacterial and parasitic pathogens in occurrence of neonatal diarrhoea in goat-kids. J. Anim. Res., 10(3) 389-395.

Source of Support: None; Conflict of Interest: None 
(Johnson et al., 1999). Klebsiellas spp, a Gram-negative, bacterium may cause diarrhoea in farm animals (Ryan and Ray, 2004; Herrera-Luna et al., 2009). Considering the importance of infectious diarrhoea in neonatal goat-kids, the present study was planned to isolate, and to identify different bacterial and parasitic pathogens associated with diarrhoea in neonatal goat-kids, so that control and preventive strategies against the pathogens may be devised.

\section{MATERIALS AND METHODS}

\section{Sample collection}

During Dec 1, 2012-March 31, 2014; 210 faecal samples were collected from diarrhoeic neonatal goat-kids $(n=210)$ of Jamunapari, Jakhrana and Barbari breeds of goat from different livestock sheds of the Institute (ICAR-CIRG, Makhdoom, Mathura) using sterile swabs (HiMedia). The swabs were kept on the ice, and immediately brought to the Laboratory, Division of Animal Health, ICAR-Central Institute for Research on Goats, Makhdoom, Farah, Mathura (Uttar Pradesh), India.

\section{Isolation and identification of $E$. coli}

All faecal samples collected were initially inoculated on sterile blood agar (5\% de-fibrinated sheep blood), and incubated at $37^{\circ} \mathrm{C}$ for $18-24 \mathrm{hr}$. Thereafter, colonies from the blood agar were inoculated on MacConkey agar, and incubated overnight at $37^{\circ} \mathrm{C}$. The pink coloured colonies grown on MacConkey agar, were further re-inoculated on Eosin Methylene Blue (EMB) agar, and incubated at $37^{\circ} \mathrm{C}$ for 18-24 hr.

\section{Biochemical tests}

For biochemical identification of E. coli, Salmonella spp. and Klebsiella spp., the biochemical tests viz. Catalase, Oxidase and IMViC were performed as per the standard bacteriological protocols (Cowan and Steel, 1975).

\section{Detection of pathogenicity of $E$. coli}

Congo red dye agar test was carried out to determine the invasiveness (pathogenicity) of the E. coli isolates as per the technique recommended by Berkhoff and Vinal (1986).
The test was performed using soyabean casein digest medium containing $0.03 \%$ Congo red dye. Appearance of red colonies within $72 \mathrm{hr}$ was recorded as a positive reaction (invasive $E$. coli). The colonies which did not bind the dye, and remained white or grey even after $72 \mathrm{hr}$, were declared negative for Congo red dye binding activity.

\section{Serotyping of isolates}

A total of 64 isolates of $E$. coli were sent to National Salmonella and Escherichia Centre, Central Research Institute, Kasauli, India for the serotyping.

\section{Molecular detection of $E$. coli}

The genomic DNAs from all E. coli isolates $(\mathrm{n}=178)$ was extracted by hot-chill method as described by Yang et al. (2008). The molecular identification of E. coli was done by PCR amplification of the universal stress protein $\mathrm{A}$ (usp $\mathrm{A}$ ) gene using species specific primers, (F-5'-CCGATACGCTGCCAATCAGT-3' \& R-5ACGCAGACCGTAGGCCAGAT-3') as used by Mishra et al. (2017). The annealing temperature was kept at $55^{\circ} \mathrm{C}$ for $0.5 \mathrm{~min}$. Thereafter, the identification of shiga toxin producing $E$. coli (STEC) or verotoxin producing E. coli (VTEC) was done by PCR amplification of its st $x-1$ and $s t x-2$ genes as per the protocols of Islam et al. (2007) and Rahman et al. (2008), respectively. The sequences of the primers used for the PCR amplification of $s t x$ - 1 gene were F-5'-CACAATCAGGCGTCGCCAG CGCACTTGCT-3' and R-5'-TGTTGCAGGGATCAG TCGTACGGGGATGC-3', whereas for $s t x$-2 gene, were F-5' 'ATCCTATTCCCGGGAGTTTACG-3' and R-5'GCGTCATCGTATACACAGGAGC-3'. The annealing temperature for the above PCRs was kept at $58{ }^{\circ} \mathrm{C}$ for 0.5 minute.

\section{Isolation and identification of Salmonella spp. and Klebsiella spp.}

The diarrhoeic samples $(\mathrm{n}=210)$ intended for Salmonella spp. isolation were initially inoculated into Rappaport Vassiliadis broth $(10-15 \mathrm{ml})$, and incubated overnight at $37^{\circ} \mathrm{C}$. The overnight growth was inoculated on blood agar. After overnight incubation, the colonies grown on blood agar were inoculated on Bismuth Sulphite agar (BSA), and the colonies on BSA were further inoculated on 
Deoxycholate Citrate agar (DCA). The molecular detection of Salmonella spp. was done by PCR amplification using the published genus specific primers (Cohen et al., 1993) (F-5'-ACTGGCGTTATCCCTTTCTCTGGTG-3' \& R-5'-ATGTTGTCCTGCCCCTGGTAAGAGA-3'). The annealing temperature was kept at $60{ }^{\circ} \mathrm{C}$ for 0.5 min. Likewise, the samples, intended for Klebsiella spp. isolation, were immediately inoculated on the sterile blood agar plates, and incubated at $37^{\circ} \mathrm{C}$ for $24 \mathrm{hr}$. Thereafter, the growth on blood agar showing catalase positive, oxidase negative and Gram-negative reactions were inoculated on MacConkey and EMB agars, and then incubated at $37{ }^{\circ} \mathrm{C}$ for $24 \mathrm{hr}$. The growth from EMB agar was then inoculated on Klebsiella selective agar, and incubated at $37{ }^{\circ} \mathrm{C}$ for $24 \mathrm{hr}$.

\section{Detection of Cryptosporidium spp.}

A total of 148 faecal samples from diarrhoeic neonatal goat-kids were targeted for presence of Cryptosporidium spp. For detection of the oocysts of Cryptosporidium spp., modified ZN staining method was used. The nested PCR targeting the SSUrRNA gene of Cryptosporidium was performed for its confirmatory diagnosis using the published oligonucleotide primers (Rieuxet al., 2013). The sequences of the primers for primary PCR were F-5'-TTCTAGAGCTAATACATGCG-3' and R-5'CCCATTTCCTTCGAAACAGGA-3', whereas for secondary/nested PCR, were F-5'-GGAA GGGTT GTATTTATTAGATAAAG-3' and R-5'-AAGG AGTAAGGAACAACCTCCA-3'. The annealing temperatures for primary and secondary PCR were kept at $56^{\circ} \mathrm{C}$ for $1 \mathrm{~min}$ and $57^{\circ} \mathrm{C}$ for $1 \mathrm{~min}$, respectively.

\section{RESULTS AND DISCUSSION}

The growth on blood agar showing catalase positive, oxidase negative and Gram negative reactions (Gram negative rods, Fig. 1A) was then inoculated on MacConkey agar. Pink colored colonies (lactose fermentation) on MacConkey agar (Fig. 1B) were further inoculated on EMB. Colonies with a characteristic metallic green sheen on EMB agar (Fig. 1C) were indicative of E. coli. The results of IMViC tests were found as +ve, +ve, -ve, -ve. In PCR amplification of the uspA, the size of the amplified product was found 884 bp (Fig. 1D).

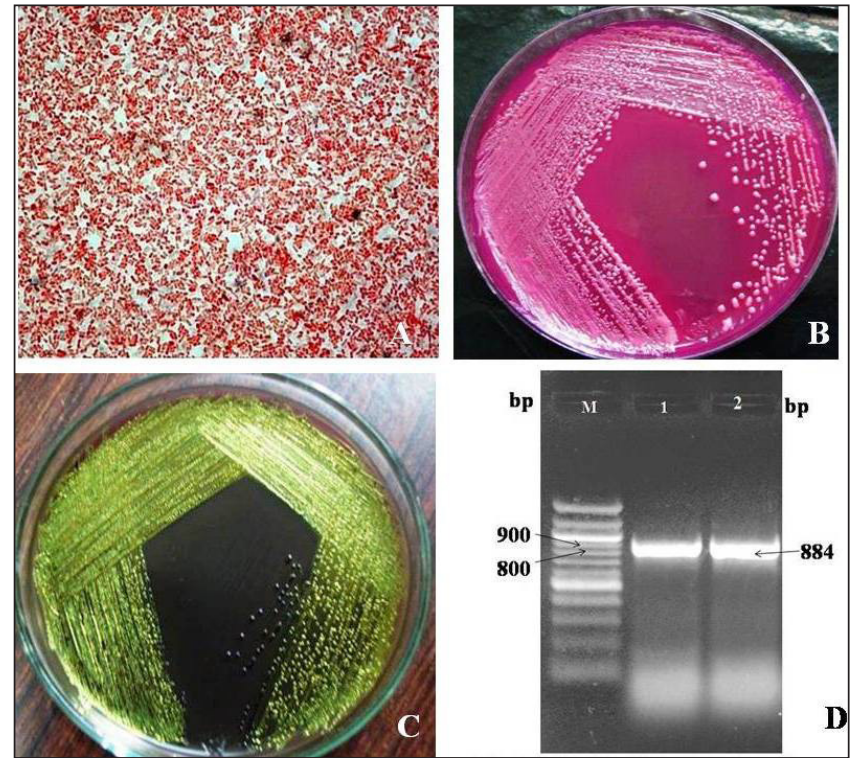

Fig. 1: Culture and isolation of E. coli from faecal samples of goat kids. (A) Gram's staining: E. coli as Gram negative rods. (B) Growth characteristics on MacConkey agar showing lactose fermentation. (C) Growth characteristic on Eosin Methylene blue agar showing characteristic green metallic sheen. (D) PCR amplification of uspA gene; Lane M; Marker; Lane 1, 2: Amplified products

From 210 faecal samples, 178 isolates of E. coli were identified on the basis of cultural, morphological, biochemical and molecular characteristics (Table 1). All of the 178 isolates showed $100 \%$ Congo red binding activity (Fig. 2), where as Kalorey et al. (2002) reported 89.09\% Congo red binding in his study.

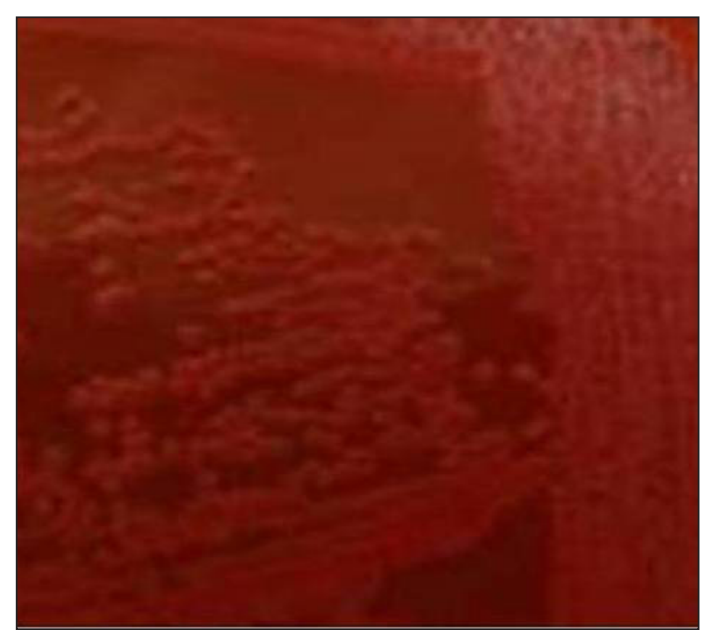

Fig. 2: E. coli showing Congo red binding activity 
Out of 178 isolates of $E$. coli from the diarrheic neonatal kids, $3.93 \%$ (7/178) were identified as STEC by PCR amplification of $s t x-1$ and $s t x-2$ gene (Fig. 3A, B). Contrary to this finding, Wani et al. (2003), Bhat et al. (2008) and Bandyopadhyay et al. (2011) reported higher percent positivity, that is, $6 \%, 17.8 \%$ and $32 \%$, respectively.

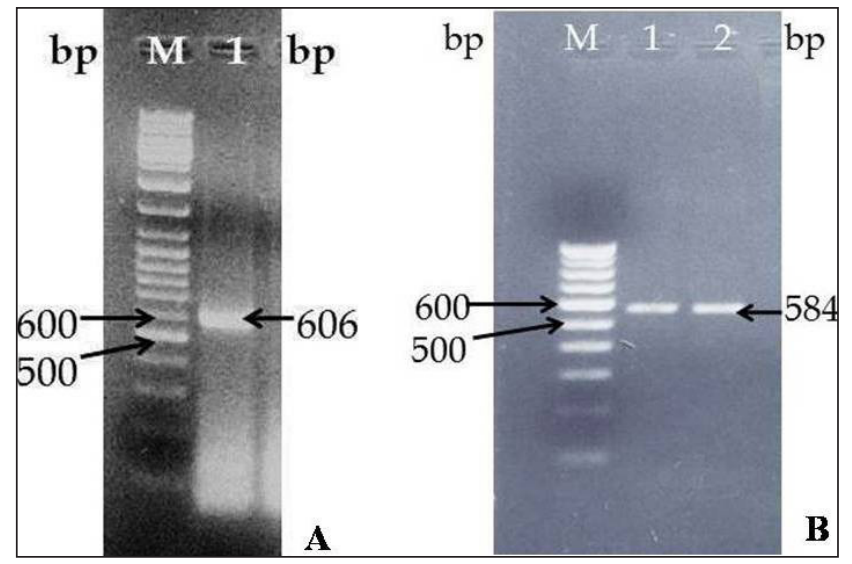

Fig. 3: PCR Amplification of $s t x-1$ and $s t x-2$ gene of STEC. (A) Lane-M: Marker; Lane-1: Amplified product; (B) Lane-M: Marker; Lane-1,2: Amplified product

A total of 64 isolates of E. coli were sent to National Salmonella and Escherichia Centre, Central Research Institute, Kasauli for the serotyping. The common serogroups of $E$. coli responsible for neonatal diarrhoea in goat-kids were identified as O36, O26, O59, O29, O43, O91, O82, O9 and O171, out of which, 46.15\% were O36, O26 and O59. In another study, Mishra et al. (2019), O88, $\mathrm{O} 22$, $\mathrm{O} 11$ and $\mathrm{O} 83$ were found as the most frequently isolated serogroups from diarrheic neonatal goat-kids, whereas Pachaury and Kataria (2012) found O55 as the most frequently serogroup associated with diarrhoea in neonatal goat-kids.

The growth on blood agar showing catalase positive, oxidase negative and Gram negative reactions (Fig. 4A), black colored colonies on BSA (Fig. 4B) and colonies with a black center surrounded by a wide light-colored rim on DCA (Fig. 4C) were indicative of Salmonella spp. The results of IMViC tests were obtained as -ve, +ve, -ve, +ve. Cultural, morphological and biochemical characteristics indicated the confirmatory diagnosis of Salmonella spp. The above findings were in accordance with the earlier findings of Saha et al. (2014). The molecular confirmation of Salmonella spp. was done by the PCR and the size of the amplified product was obtained as 496 bp (Fig. 4D). In present study, 7.62\% (16/210) samples were positive for Salmonella spp. (Table 1). Zaki et al. (2010) found $27 \%$ of diarrhoeic faecal samples positive for Salmonella spp. in his study, whereas Munoz et al. (1996) reported Salmonella spp. presence in $2.7 \%$ samples. In five cases of the neonatal diarrhoea, Salmonella was found as single causative agent of the diarrhoea indicating its ability to cause disease alone.

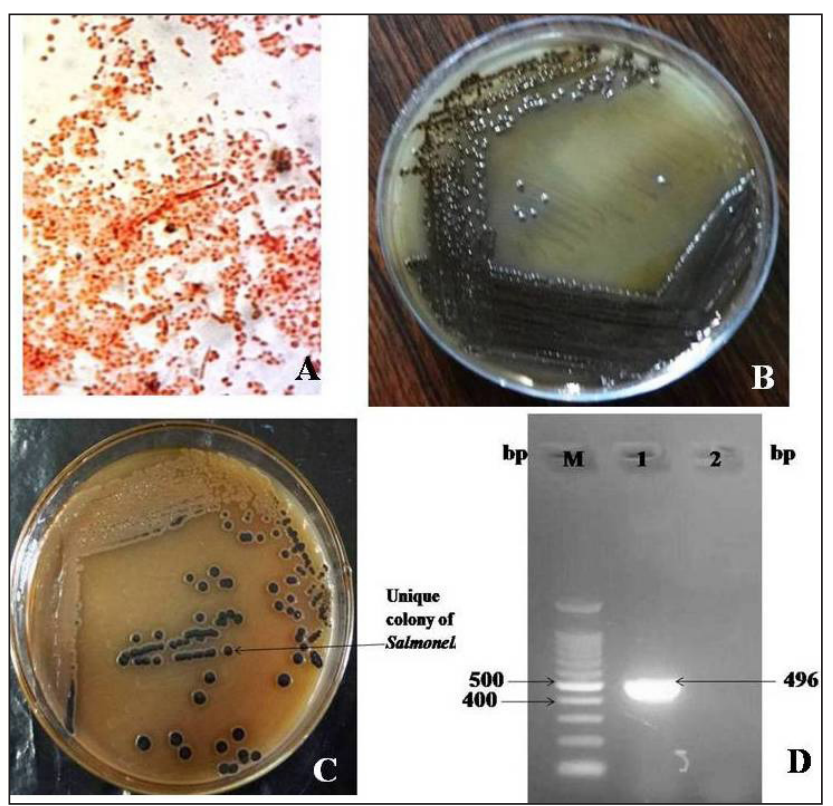

Fig. 4: Culture and isolation of Salmonella from faecal samples of goat kids. (A) Gram's staining: Salmonella as Gram negative rods. (B) Growth characteristics on Bismuth Sulphite agar showing black coloured colonies. (C) Growth characteristic on Deoxycholate citrate agar. (D) PCR for identification of Salmonella; Lane M; Marker; Lane 1: Amplified product; Lane2: Control

For Klebsiella spp. isolation, the colonies showing catalase positive, oxidase negative, IMViC reactions as -ve, -ve, +ve, +ve and Gram negative reactions (Fig. 5A), were selected. Mucoid pink colored colonies (lactose fermentation, Fig. 5B) on MacConkey agar and Fisheye type colonies (a dark center surrounded by a wide, light-colored, mucoid rim) on EMB agar (Fig. 5C) were indicative of Klebsiella spp. Presence of the purple coloured colonies on the Klebsiella selective agar (Fig. 5D) indicated the confirmatory diagnosis of Klebsiella spp. Presence of Klebsiella spp. was found in $2.38 \%$ of diarrheic samples $(5 / 210)$ of the neonatal goat-kids 
as presented in Table 1. In our study, diarrhoegenic E. coli was also isolated from the five Klebsiella positive samples. Hence, Klebsiella spp. alone was not found to cause diarrhoea in the goat-kids. This finding is contrary to the findings of Ryan and Ray, (2004) and Herrera-Luna et al. (2009), in which Klebsiella spp. alone was found capable to cause diarrhoea.

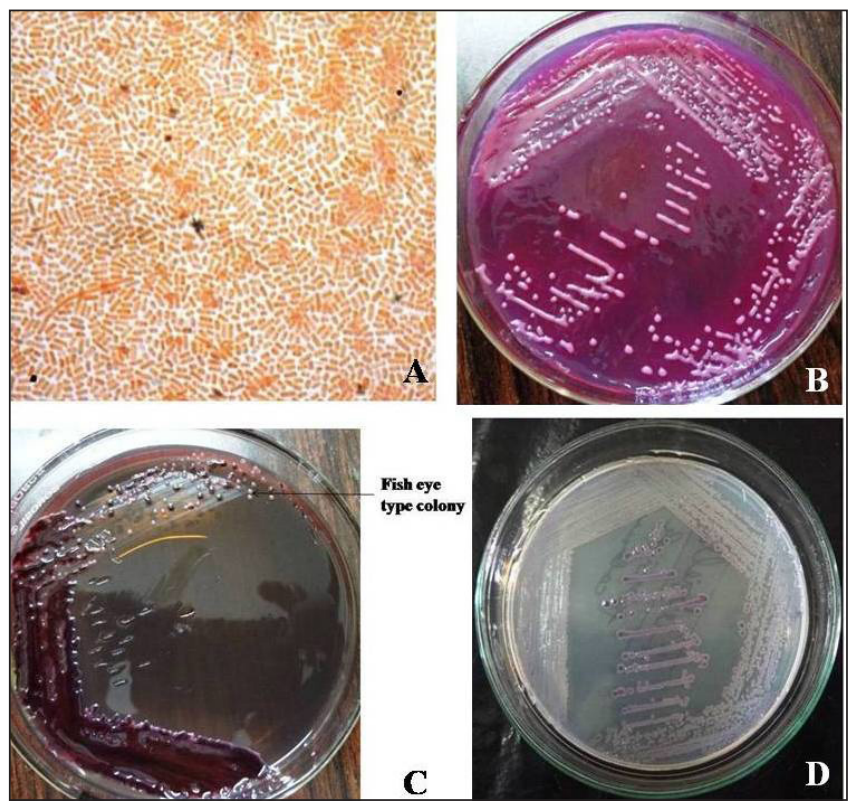

Fig. 5: Culture and isolation of Klesiella from faecal samples of goat kids. (A) Gram's staining: Klebsiella as Gram negative rods. (B) Mucoid colonies on MacConkey agar. (C) Fish eye type colonies on EMB. (D) Klebsiella on selective media

Table 1: The breed wise distribution of the identified bacterial pathogens from the neonatal diarrhoea in goat-kids

\begin{tabular}{|c|c|c|c|c|}
\hline $\begin{array}{l}\text { Breed of } \\
\text { goat }\end{array}$ & $\begin{array}{l}\text { Number } \\
\text { of Faecal } \\
\text { Samples } \\
\text { Collected }\end{array}$ & $\begin{array}{l}\text { Percent } \\
(\%) \text { of } \\
\text { E. coli } \\
\text { Positive } \\
\text { Samples }\end{array}$ & $\begin{array}{l}\text { Percent } \\
(\%) \text { of } \\
\text { Salmonella } \\
\text { Positive } \\
\text { Samples }\end{array}$ & $\begin{array}{l}\text { Percent (\%) } \\
\text { of Klebsiella } \\
\text { positive } \\
\text { Samples }\end{array}$ \\
\hline Jamunapari & 99 & 83.83 & 8.08 & 2.02 \\
\hline Barbari & 100 & 86.00 & 6.00 & 3.00 \\
\hline Jakhrana & 11 & 81.82 & 18.81 & - \\
\hline Total & 210 & 84.76 & 7.62 & 2.38 \\
\hline
\end{tabular}

Out of 148 samples, the presence of Cryptosporidium spp. was found in 46 samples by modified ZN staining method (Table 2; Fig. 6A) and the nested PCR targeting the SSU rRNA gene of Cryptosporidium spp. It resulted in to the amplicon with size of 834 bp (Fig. 6B). From 16 samples positive for Cryptosporidium spp., no bacterial agent targeted in the present study was isolated indicating its capability to cause neonatal diarrhoea as sole pathogen. Munoz et al. (1996) detected Cryptosporidium parvum in diarrhoeic goat-kids with $42 \%$ positivity but not in nondiarrhoeic animals, which supports our finding.

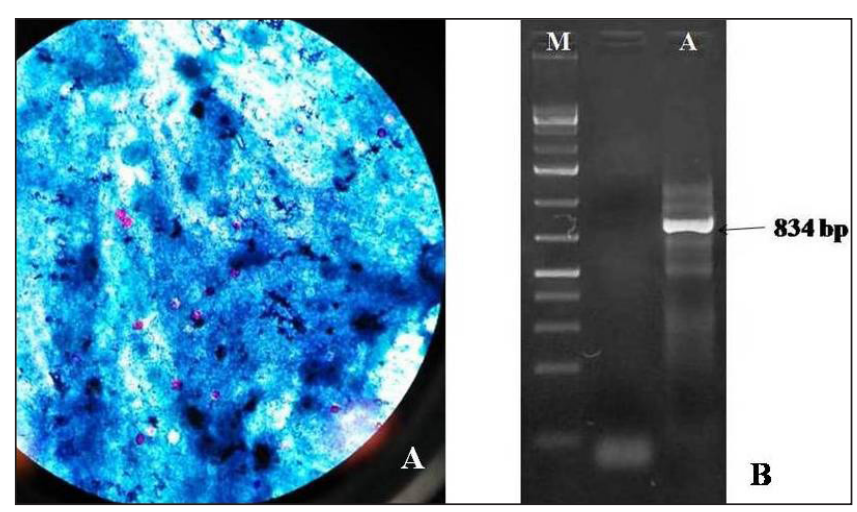

Fig. 6: Showing Cryptosporidium spp., (A) By modified ZN staining, (B) Amplification of 18s sRNAgene of Cryptosporidium spp., Lane-M: 100bp marker; Lane-a: Nested product

Table 2: Breed wise presence of Cryptosporidium in diarrhoeic feces of the neonatal kids

\begin{tabular}{llll}
\hline $\begin{array}{l}\text { Breed of } \\
\text { goat }\end{array}$ & $\begin{array}{l}\text { Total } \\
\text { Number of } \\
\text { Diarrheic } \\
\text { Samples }\end{array}$ & $\begin{array}{l}\text { Total Positive } \\
\text { Samples for } \\
\text { Cryptosporidium }\end{array}$ & $\begin{array}{l}\text { Percent (\%) of } \\
\text { Cryptosporidium } \\
\text { Positive Samples }\end{array}$ \\
\hline Barbari & 61 & 19 & 31.2 \\
Jamunapari & 55 & 18 & 32.8 \\
Jakhrana & 32 & 9 & 28.1 \\
\hline Total & $\mathbf{1 4 8}$ & $\mathbf{4 6}$ & $\mathbf{3 0 . 7}$ \\
\hline
\end{tabular}

The results of current study suggest that $E$ coli were found to be the main causative agents associated with the neonatal diarrhoea in the goat kids. Salmonella spp. and Cryptosporidium spp. were also found capable to cause the diarrhoea in the kids. Other researchers (FassiFehri et al., 1988; Ozmen et al., 2006; Paul et al., 2014) also indicated same findings in their studies. The results from the study would serve as basic data for designing the diagnostics, prophylaxis and the package of practices to control/prevent the diarrhoea in the neonatal goatkids. The data would help in understanding the pattern of 
distribution of the bacterial and parasitic agents associated with diarrhoea in the kids.

\section{ACKNOWLEDGEMENTS}

Authors are thankful to the Director, Central Institute for Research on Goats (ICAR-CIRG), Makhdoom, Farah, Mathura-281122, Uttar Pradesh (India) for providing necessary facilities to carry out the present study.

\section{REFERENCES}

Bandyopadhyay, S., Mahanti, A., Samanta, I., Dutta, T.K., Ghosh, M.K., Bera, A.K., Bandyopadhyay, S. and Bhattacharya, D. 2011. Virulence repertoire of Shiga toxin-producing Escherichia coli (STEC) and enterotoxigenic Escherichia coli (ETEC) from diarrhoeic lambs of Arunachal Pradesh, India. Trop. Anim. Health Prod., 43(3): 705-710.

Berkhoff, H.A. and Vinal, A.C. 1986.Congo red medium to distinguish between invasive and non- invasive Escherichia coli pathogenic for poultry. Avi. Dis., 30: 117-121.

Bhat, M.A., Nishikawa, Y. and Wani, S.A. 2008. Prevalence and virulence gene profiles of Shiga toxin-producing Escherichia coli and enteropathogenic Escherichia coli from diarrhoeic and healthy lambs in India. S. Rumin. Res., 75(1): 65-70.

Cohen, N.D., Neibergs, H.L., McGruder, E.D., Whitford, H.W., Behle, R.W., Ray, P.M., and Hargis, B.M. 1993. Genusspecific detection of salmonellae using the polymerase chain reaction (PCR). J. Vet. Diagn. Invest., 5: 368-371.

Coura, F.M., Freitas, M.D., Ribeiro, J., de Leme, R.A., de Souza, C., Alfieri, A.A., Facury F.E.J., de Carvalho, A.Ú., Silva, M.X., Lage, A.P. and Heinemann, M.B., 2015. Longitudinal study of Salmonella spp., diarrheagenic Escherichia coli, Rotavirus, and Coronavirus isolated from healthy and diarrheic calves in a Brazilian dairy herd. Trop. Anim. Health Prod., 47(1): 3-11.

Cowan, S.T. and Steel, K.J. 1975. Manual for the identification of medical bacteria. Cambridge University Press, Cambridge.

Draksler, D., Locascio, M., González, S. and Oliver, G. 2002. The development of faecal flora in young Creole goats. $S$. Rumin. Res., 46: 67-70.

Herrera-Luna, C., Klein, D., Lapan, G., Revilla- Fernandez, S., Haschek, B., Sommerfeld-Stur, I., Moestl, K. and Baumgartner, W. 2009. Characterization of virulence factors in Escherichia coli isolated from diarrheic and healthy calves in Austria shedding various enteropathogenic agents. Veterinarni. Medicina, 54: 1-11.

Islam, M.A., Heuvelink, A.E., De Boer, E., Sturm, P.D., Beumer, R.R., Zwietering, M.H. and Talukder, K.A. 2007. Shiga toxin-producing Escherichia coli isolated from patients with diarrhoea in Bangladesh. J. Med. Microbiol., 56(3): 380-385.

Johnson, E.H., Muirhead, D.E., Windsor, J.J., King, G.J., AlBusaidy, R. and Cornelius, R. 1999. Atypical outbreak of caprine cryptosporidiosis in Sultanate of Oman. Veterinary Record, 145: 521-524.

Kalorey, D.R., Kurkene, N.V., Hame, S.D., Ingle, V.C., Patil, A.A., Sakhare, P.S., WARKE, S.R. 2002. Congo red binding ability of Escherichia coli. Indian J. Comp. Microbiol. Immunol. Infect. Dis., 23: 79-80.

Kritas, S.K. 2002. Prevention of scours due to Escherichia coli in neonatal kids by oral administration of an organic acid solution. J. Vet. Med., 49: 23-26.

Mishra, A.K., Singh, D.D., Gururaj, K., Kumar, A., Dixit, A., Shrama, N., Gupta, G. and Yadav, S. 2019. Molecular characterization of diarrhoegenic Escherichia coli isolated from neonatal goat-kids. J. Ani. Res., 9: 1-9.

Mishra, A.K., Singh, D.D., Kumarsen, G., Gupta, G., Sharma, N., Kumar, N., Nayakvadi, S. and Paul, S. 2017. UspA gene based characterization of Escherichia coli strains isolated from different disease conditions in goats. J. Ani. Res.,7: 1123-1128.

Munoz, M., Alvarez, M., Lanza, I. and Carmenes, P. 1996. Role of enteric pathogens in the aetiology of neonatal diarrhoea in lambs and goat kids in Spain. Epidemiol. Infect., 117: 203211.

Ozmen, O., Yukari, B.A., Haligur, M. and Sahinduran, S. 2006. Observations and immuno-histochemical detection of coronavirus, Cryptosporidium parvum and Giardia intestinalis in neonatal diarrhoea in lambs and kids. Schweiz Arch. Tierh., 148: 357-364.

Pachaury, R. and Kataria, A.K. 2012. Serogrouping and colicinrelated properties of Escherichia coli isolated from neonatal diarrheic ruminants. Rumin. Res., 1(1): 9-13.

Paul, S., Sharma, D.K., Boral, R., Mishra, A.K., Shivsharanappa, N., Banerjee, P.S. and Pawaiya, R.V.S. 2014. Cryptosporidiosis in goats- a review. Adv. Anim. Vet. Sci., 2: 49 - 54.

Radostits, O.M., Gay, C.G., Blood, D.C. and Hinchcliff, K.W. 2006. Diseases caused by bacteria. In: Veterinary Medicine: A textbook of the diseases of cattle, sheep, pigs, goats and horses. Saunders, London, $10^{\text {th }}$ edition, pp. 753-822.

Rahman, H., Begum, R.H., Urugkar, H.V.M., Rahman, H., Kumar, A., Shome, B.R. and Shome, R. 2008. Occurrence and distribution of virulence factors among clinical isolates of non-O-157 Escherichia coli. J. Vet. Pub. Hlth., 6(1): 09-13

Rieux, A., Paraud, C., Pors, I. and Chartier, C. 2013. Molecular characterization of Cryptosporidium spp. in pre-weaned kids in a dairy goat farm in western France. Vet.Parasitol., 192: 268-272. 
Ryan, K.J. and Ray, C.G. 2004. Sherris Medical Microbiology, $4^{\text {th }}$ ed. McGraw Hill, pp. 370.

Saha, G.K., Paul, A.K., Samad, M.A., Islam, M.A. and Khan, M.S.R. 2014. Prevalence of Salmonella associated with goats in Bangladesh. Suranaree J. Sc. Tech., 21: 193-199.

Singh, D.D., Pawaiya, R.V.S., Gururaj, K., Gangwar, N.K., Mishra, A.K., Singh, R. and Kumar, A. 2018. Detection of Clostridium perfringens toxinotypes, enteropathogenic E. coli, Rota and corona viruses in the intestine of neonatal goat kids by molecular techniques. Indian J. Anim. Sc., 88(6): 655-661.

Smith, M.C. and Sherman, D.M. 2009. Wiley-Blackwell Publication, Iowa (USA), ${ }^{\text {nd }}$ Edition. Goat Medicine.
Wani, S.A., Samanta, I., Munshi, Z.H., Bhat, M.A. and Nishikawa, Y. 2006. Shiga toxin-producing Escherichia coli and enteropathogenic Escherichia coli in healthy goats in India: occurrence and virulence properties. J. Appl. Microbiol., 100: 108-113.

Yang, J.L., Wang, M.S., Cheng, A.C., Pan, K.C., Li, C.F. and Deng, S.X. 2008. A simple and rapid method for extracting bacterial DNA from intestinal microflora for ERIC-PCR detection. World J. Gastroenterol., 14(18): 2872.

Zaki, M.S., Ata, N.S. and Shalaby, I., 2010. Diarrhoea in Neonatal baraki kids-goats. Marsland Press, 7: 93-97. 
